http://dx.doi.org/10.12775/szhf.2018.006

\author{
AdAM GrZEgorzyCA \\ Uniwersytet Opolski, Opole, Polska \\ e-mail: grzegorzycaadam@gmail.com
}

\title{
Platońskie idee i Eriugeny przyczyny prymordialne w kontekście ich pochodzenia, realności i autonomii
}

\author{
Wstęp
}

W systemie filozoficznym Platona idee to wieczne i niezmienne byty warunkujące istnienie zmiennej rzeczywistości. Koncepcja idei stanowi fundament systemu Platona i najważniejszy jego aspekt. Fenomeny są tym, czym są, ponieważ uczestniczą w ideach. Dusza ludzka pozbawiona ciała miała dostęp do świata idei, a ludzki intelekt, według Platona, powinien wznosić się ku ich poznaniu. W systemie filozoficznym Eriugeny przyczyny prymordialne to pierwotne przyczyny wzorcze, które stanowią jeden z czterech elementów podziału natury, czyli podziału wszystkiego. Koncepcja czwórpodziału natury stanowi fundament systemu Eriugeny i najważniejszy jego aspekt. Przyczyny prymordialne to natura druga - stworzona natura stwarzająca. Przyczyny istnieją w Synu Bożym - Logosie, a ludzki intelekt, według Eriugeny, powinien wznosić się ku ich poznaniu. Niniejszy artykuł jest próbą ukazania idei i przyczyn w trzech, ważnych zdaniem autora kontekstach, dotyczących źródeł pochodzenia, realności istnienia oraz autonomii. 


\section{Pochodzenie idei i przyczyn prymordialnych}

W systemie filozoficznym Platona rzeczywistość posiada strukturę hierarchiczną. Najwyżej usytuowane są pierwotne zasady: Jedno i Diada. Nieokreślona Diada jest podporządkowana Jednu, lecz jako nieokreśloność jest związana $\mathrm{z}$ Jednem i współwieczna. Z pierwotnych zasad wynika świat idei. Poniżej sytuuje się świat bytów matematycznych i najniżej rzeczywistość zmysłowa, o której nic pewnego nie można orzekać. Strukturalna nadrzędność pierwotnych zasad oraz wynikanie z nich świata idei nie mają wpływu na ontologiczny status idei, ponieważ Jedno i Diada nie są stwórcami idei, choć G. Reale przyjmuje, że idee jako byty pochodzą od Jedna i Diady w tym sensie, że stanowią wytwór jedności i nieokreśloności - są syntezą jedności, która determinuje i nieokreśloności, która nie determinuje lub jedności, która ogranicza i nieokreśloności, która nie ogranicza ${ }^{1}$. Nie oznacza to jednak, że ontologicznie idee zostały złożone w procesie jakiejś syntezy z różnych części, do których mogą znów powrócić na skutek rozpadu. Zasady uzasadniają, lecz nie stwarzają idei, które w sensie ontologicznym są bytami wiecznymi, czyli niestworzonymi, ponieważ według Platona nigdy nie mogło być tak, że idei nie było. W Fedonie Platon pisze „[... ] cokolwiek zawsze zostaje takie samo i niezmienne, to przede wszystkim będzie niezłożone [...]”2. Idee to byty „[...] nieśmiertelne, i dla myśli tylko dostępne, i jedną tylko postać mające, i nierozkładalne, i zawsze samo w sobie jednakie [... ”’3. Idee istnieją zawsze i nigdy nie zostały stworzone, ponieważ nigdy nie podlegały żadnej zmianie. Zawsze pozostają wieczne i niezmienne ${ }^{4}$.

W systemie filozoficznym Eriugeny bezpośrednim źródłem przyczyn prymordialnych jest mądrość Boga, czyli odwieczny Logos - Boże Słowo. Racjonalna argumentacja jest $\mathrm{w}$ systemie Eriugeny silnie związana $\mathrm{z}$ biblijną egzegezą. Filozof przyjmuje, że egzegeza Biblii i analiza stworzenia to dwa równoprawne źródła wiedzy o rzeczywistości, ponieważ autorem specyficznie rozumianej księgi Natury i księgi Pisma jest jeden Bóg, który obdarował ludzkość tymi dwiema księgami, by przez ich poznawanie człowiek mógł po-

${ }^{1}$ Zob. G. Reale, Historia filozofii starożytnej, t. II: Platon i Arystoteles, przeł. E. I. Zieliński, RW KUL, Lublin 1996, s. 117-121.

${ }^{2}$ Platon, Fedon, 78 c, [w:] tenże, Dialogi, t. I, przeł. oraz wstępami i objaśnieniami opatrzył W. Witwicki, ANTYK, Kęty 2005, s. 660.

${ }^{3}$ Tamże, 80b, s. 663.

${ }^{4}$ Zob. tamże, 78d, s. 660. 
znać swego Stwórcę i do Niego wrócićs. Analizując przyczyny prymordialne w ujęciu egzegetycznym, Eriugena pisze: „A zatem powiedz, proszę, co rozumiesz, gdy słyszysz Boże słowa: „Na początku stworzył Bóg”. Nic innego nad to, co ustaliliśmy: że Ojciec w swoim Słowie wszystko uczynił. Kiedy bowiem słyszę „Bóg”, to myślę o Bogu Ojcu, a kiedy słyszę „Początek”, rozumiem Boga-Słowo"6. Przyczyny prymordialne zaistniały więc poprzez jeden akt ustanowienia ich w Logosie - Słowie - Początku. Uzasadniając swój pogląd, Eriugena pisze: „Ponieważ nie jest czym innym Początek, czym innym Mądrość, czym innym Słowo, lecz tymi wszystkimi nazwami w sposób właściwy określony jest Jednorodzony Syn Boży, w którym i przez którego Ojciec wszystko uczynił"7. Bóg jest wiecznością i nie posiada początku, lecz dla ukazania relacji Syna do przyczyn prymordialnych, Syn otrzymuje miano Początku. Bóg Ojciec zrodził Syna - Logos i ustanowił w Synu wszystko, co wieczne. Eriugena uważa, że poza Bogiem w sensie właściwym nic nie istnieje, więc odwiecznym Logosem jest Bóg Jezus Chrystus. Przyczyny zostały ustanowione w Logosie - Słowie, które nie jest stworzone, lecz zrodzone. Przyczyny zaś nie są zrodzone, lecz są w Logosie od zawsze, ponieważ nigdy nie było takiego momentu, że przyczyn w Logosie nie było. Przyczyny są stworzone, ale jednocześnie są wieczne, bo Logos jest wieczny. Nie oznacza to jednak, że w jakiejkolwiek mierze przyczyny można zrównać z Bogiem i zrodzonym Logosem, ponieważ Bóg nie posiada swej przyczyny, a przyczyny zostały ustanowione przez Boga i nie istnieją same przez się. Przyczyny prymordialne to idee, pierwotne wzory i już nic więcej nie powstaje, ponieważ wszystko, co zostało do rzeczywistości przez Boga dopuszczone, zostało

\footnotetext{
${ }^{5}$ Zob. Eriugena, Periphyseon, Ksiega I, Wstęp, s. 37-38 oraz A. Kijewska, Księga Pisma i Ksiega Natury. Heksameron Eriugeny $i$ Teodoryka $z$ Chartres, Wydawnictwo KUL, Lublin 1999, s. 64 i n. oraz W. Otten, Nature and Scripture: Demise of a Medieval Analogy, „Harvard Theological Review", 1995, 88/2, s. 257 i n.

${ }^{6}$ Eriugena, Periphyseon, Księga II, przeł., wstępem i komentarzami opatrzyła A. Kijewska, Wydawnictwo Marek Derewiecki, Kęty 2010, s. 127 oraz s. 126 za Eriugena, Periphyseon, liber secundus, opracowany przez E. Jeauneau dla serii „Corpus Christianorum. Continuatio Mediaevalis” 162, Turnhout 1997: „N. Dic itaque, quaeso, quid intelligis, quando theologiam dicentem audis: „In principio fecit deus”. A. Nil aliud nisi quod inter nos convenerat, patrem in verbo suo omnia fecisse. Dum enim deum audio, deum patrem cogito; dum principium, intelligo deum verbum".

7 Tamże, s. 147 oraz s. 146 za Eriugena, Periphyseon, liber secundus: Non enim aliud est principium, aliud sapientia, aliud verbum, sed his omnibus nominationibus [unigenitus] filius dei, in quo et per quem omnia a patre facta sunt, proprie significatur.
} 
ustanowione $\mathrm{w}$ Logosie poza czasem i przestrzenią̧${ }^{8}$. Wskazując na wieczność stworzonych przyczyn - idei, Eriugena wydaje się nawiązywać do myśli św. Augustyna, który przyjmował takie rozwiązanie. W systemie Eriugeny stanowi ono newralgiczną, lecz fundamentalną prawdę o jednoczesnej stworzoności i wieczności przyczyn ustanowionych przez Boga w jego Słowie ${ }^{9}$. Chrześcijański neoplatonizm przyjął doktrynę stworzenia $\mathrm{z}$ niczego, więc przyczyny prymordialne zostały stworzone z nicości, która musi oznaczać w tym kontekście coś bardzo wielkiego i szczególnego. Eriugena uważa, że niezależnie od doniosłości nicości, nie jest ona czymś zewnętrznym wobec Boga, który nie potrzebował niczego zewnętrznego dla stworzenia przyczyn wszystkiego. Eriugena pisze: „Zrozum, że dzięki mocy Bożej Dobroci z tego, co nie istnieje, powstały rzeczy istniejące, gdyż to, czego nie było, zaczęło istnieć. Istotnie, zostały one stworzone $\mathrm{z}$ niczego, ponieważ nie istniały, zanim się stały" ${ }^{\prime 10}$. Nicość, $\mathrm{z}$ której w Logosie powstały prymordialne przyczyny, to Boża dobroć ${ }^{11}$, której jasność jest absolutnie wieczna i przewyższająca wszystko ${ }^{12}$.

\section{Realność istnienia idei i przyczyn prymordialnych}

Platońskie idee są realne w tym sensie, że w swej określoności są w pełni niezależne od bycia czymkolwiek innym niż tym, czym są. Idea piękna jest realną ideą, która jest niezależna od hipotetycznej możliwości bycia czymś innym. Określona idea jest realna i nie może być niczym innym. Realny charakter idei powoduje, że nie zachodzi możliwość realnego istnienia przeciwieństwa danej idei. Istniejące w zmiennym świecie fenomeny, np. ludzie,

${ }^{8}$ Zob. tamże, s. 309.

9 Zob. D. J. O'Meara, Eriugena's Use of Augustine's „De Genesi ad litteram” in the „Periphyseon”, [w:] Studies in Augustine and Eriugena, ed. T. Halton, The Catholic University of America Press, Washington 1992, s. 271 i n.

${ }^{10}$ Eriugena, Periphyseon, Księga III, przeł., wstępem i komentarzami opatrzyła A. Kijewska, Wydawnictwo Marek Derewiecki, Kęty 2010, s. 101 oraz s. 100 za Eriugena, Periphyseon, liber tertius, opracowany przez E. Jeauneau dla serii „Corpus Christianorum. Continuatio Mediaevalis" 163, Turnhout 1999: Intellige ex non existentibus existentia virtute bonitatis divinae facta fuisse. Ea enim quae non erant acceperunt esse. De nihilo nanque facta sunt, quia non erant priusquam fierent.

11 Zob. tamże, s. 241.

${ }^{12}$ Zob. tamże, s. 239-241. 
mogą być sprawiedliwi lub niesprawiedliwi. Człowiek może być pod pewnym względem uczciwy, a pod innym względem może już nie być uczciwy. Idea uczciwości natomiast w żadnej mierze nie może stać się ideą nieuczciwości. Gdyby było inaczej, wówczas w jednej idei istniałaby uczciwość sama i nieuczciwość sama, więc idea składałaby się z części. Platon nie dopuszcza takiego rozwiązania, co jednocześnie oznacza, że nie mogą istnieć idee negacji. W Protagorasie Platon pisze: „A czy ta sprawa, ona sama, zdaniem waszym, wychodzi na to, czy być bezbożnym, czy być pobożnym? Ja bym się, mówię, oburzył na takie pytanie i powiedziałbym: Nie obrażaj boga, człowiecze: toż przecie tym mniej cokolwiek innego może być pobożnym, jeżeli sama pobożność nie będzie tym, co pobożne"13. Platońskie rozwiązanie jest jasne, ale naturalne wydaje się pytanie, co z powszechnikami, które są negacjami, a które według Platona nie mogą być ideami? Dostrzegając zbiór powszechników, do którego należą idee i ich negacje, wydaje się, że należy wyodrębnić podzbiór powszechników, będących ideami i podzbiór powszechników, nie będących ideami. Komentując Metafizykę Arystotelesa, Syrian zwrócił uwagę, że istnienie idei negacji skutkowałoby rozpadem samych idei oraz definicji, jakie dla wszystkiego z idei wynikają. Według Syriana nie istnieją idee poszczególnych części jednej całości, np. głowy czy nóg; nie istnieją również idee zmanipulowanych gatunków zwierząt i roślin, ponieważ są one produktem pogwałconej natury ${ }^{14}$ - są najczęściej efektem ludzkiej ingerencji. Według Syriana koncepcja idei zakłada, że istnieje wiele powszechników, lecz nie wszystkie są ideami. Te powszechniki, które są ideami istnieją realnie, natomiast pozostałe realnie istnieć nie mogą z tego powodu, że realnie istnieją tylko idee. Negacje idei to ogóły nienaturalne charakteryzujące się odstępstwem od wzoru i wybrakowaniem. Takie twory nie mogą istnieć realnie, ponieważ może istnieć pojęcie braku, ale nie istnieje idea braku. Jedność i niezłożoność idei jest według Platona jedną z najistotniejszych cech wyrażających realizm ich istnienia. W Fedonie czytamy: „Otóż, czy to nie przedmioty złożone, powstałe przez syntezę, podlegają z natury rzeczy temu stanowi: rozpadają się tak samo, jak zostały złożone. Ale jeśli coś jest niezłożone, to właśnie ono jedynie podlegać temu nie może, jeśli w ogóle cokolwiek? [...]. Nieprawdaż; cokolwiek zawsze zostaje takie samo i niezmienne, to przede wszystkim będzie niezłożone, a co raz takie, raz inne i nigdy takie samo, to będzie złożone? Mnie

${ }^{13}$ Platon, Protagoras 330d, Dialogi, t. I, dz. cyt., s. 290.

${ }^{14}$ Zob. Syrianus, Syriani In Metaphysica commentaria, ed. by G. Kroll, Commentaria in Aristotelem Graeca, Berolini, Berlin 1902, s. 107-108. 
się przynajmniej tak wydaje" ${ }^{\prime 1}$. Idee są niezłożone, więc jako takie zawsze niezmiennie realnie istnieją. Innymi cechami, które wyrażają realność idei są jednorodność i prostota. Odnosząc problem realności idei do człowieka, Platon uważa, że ludzka dusza najpodobniejsza jest do tego wszystkiego, co proste, jednorodne, wieczne, niezmienne, nierozkładalne i dostępne tylko dla intelektu, natomiast ludzkie ciało najpodobniejsze jest do tego, co śmiertelne, zmienne, wielopostaciowe, rozkładalne i bezmyślne ${ }^{16}$. Człowiek żyjący $\mathrm{w}$ zmysłowej rzeczywistości dostrzega wielorakie aspekty realnego istnienia idei, choć zachodzi niebezpieczeństwo, że ta mnogość przysłoni prawdę o ideach, które same w sobie są czymś jednym. W Państwie Platon wskazuje na piękno i brzydotę jako na dwie rzeczy, z których każda jest jedną rzeczą. Podaje przykład sprawiedliwości i niesprawiedliwości oraz dobra i zła. Podsumowując, pisze: „Każde z osobna jest czymś jednym, ale dzięki temu, że się to wiąże z działaniami i z ciałami, i ze sobą nawzajem, wszędzie się każde z nich naszej wyobraźni przedstawia jako wiele rzeczy" ${ }^{17}$. Platon wskazuje na pary przeciwieństw, na dwa powszechniki, $\mathrm{z}$ których tylko jeden posiada realne istnienie i nie zachodzi możliwość, by powszechnik nie będący ideą w jakikolwiek sposób mógł uczestniczyć w idei. Realnie istniejąca idea jest tak określona, że nie dopuszcza w jakiejkolwiek mierze swego przeciwieństwa.

Więc zobacz - powiada - co chcę jasno powiedzieć. To mianowicie, że nie tylko tamte przeciwieństwa nie znoszą się nawzajem, ale nawet i te rzeczy, które nie będąc właściwie sobie przeciwne, mają jednak coś przeciwnego w sobie, nawet $i$ te rzeczy, podobno nie są gotowe przyjmować idei, która byłaby przeciwna tej, co w nich mieszka, ale za zbliżeniem się jej albo giną, albo ustępują. Czyż nie powiemy, że trójka raczej zginie, czy nie wiadomo co się z nią stanie, zanimby wytrzymała to, żeby dalej zostać trójką, a stać się czymś parzystym? ${ }^{18}$

Idea piękna stanowiąca istotę piękna i piękno samo w sobie nie może, nie dopuszcza i nie potrafi przyjąć do siebie jakiejkolwiek brzydoty, bo wówczas nie byłaby tym, czym w swej istocie jest. W Hippiaszu większym Platon pisze: "Ja ci powiem, bo zdaje mi się, że ty szukasz w odpowiedzi takiego piękna,

\footnotetext{
${ }^{15}$ Platon, Fedon 78 c, Dialogi, t. I, dz. cyt., s. 659-660.

${ }^{16}$ Zob. tamże, 80b, s. 663.

${ }^{17}$ Platon, Państwo 476a, przeł., wstępem i komentarzami opatrzył W. Witwicki, ANTYK, Kęty 2003, s. 180.

${ }^{18}$ Platon, Fedon 104b, Dialogi, t. I, dz. cyt., s. 697.
} 
które się nigdy nigdzie nikomu szpetnym nie wyda"19. Tylko wieczna i niezmienna idea piękna nigdy nikomu nie wyda się szpetna, ponieważ niemożliwe jest posiadanie przez nią jakiegokolwiek aspektu jej negacji, która jest tylko brakiem bez realnego istnienia. W Fedonie Platon pisze:

Równość sama, piękno samo, wszystko, cokolwiek istnieje samo, każdy byt podpada kiedy jakiejkolwiek przemianie? Czy też zawsze wszystko, cokolwiek istnieje naprawdę, jedną tylko zachowuje postać samo w sobie, jednakie zawsze i niezmienne, żadnej nigdy i pod żadnym względem odmianie nie podlegając? - Zawsze zostaje takie samo, oczywiście, Sokratesie - powiedział Kebes ${ }^{20}$.

W systemie filozoficznym Eriugeny przyczyny prymordialne rozpatrywane w kontekście ludzkiego poznania są wiecznymi bytami warunkującymi istnienie wszystkich swoich skutków, a więc całego stworzenia, które właśnie $\mathrm{w}$ przyczynach pierwotnie zaistniało. Jednak przyczyny rozpatrywane $\mathrm{w}$ absolutnym sensie ontologicznym nie mają w pełni realnego istnienia, które Eriugena przypisuje tylko Bogu. Przyjmując, że realnie istnieje tylko Bóg, Eriugena nawiązuje do myśli Pseudo-Dionizego Areopagity, który podkreślał, iż Bóg jako jedyny istnieje prawdziwe i sam stanowi istotę wszystkiego. Bóg według Pseudo-Dionizego jest Bóstwem warunkującym każde inne istnienie i warunkuje każdy byt, lecz sam jest ponad wszelkim bytem ${ }^{21}$. Według Eriugeny nieskończony Bóg jest źródłem przyczyn prymordialnych, więc przyczyny również mają atrybut nieskończoności, do którego ludzkie poznanie nie sięga. Prowadząc rozważania nad przyczynami, Eriugena zwraca uwagę na różnicę, jaka zachodzi pomiędzy istnieniem przyczyn a ich poznawczym ujęciem przez człowieka, który może wnioskować o przyczynach na podstawie ich skutków i zastanawiać się nad relacją, jaka zachodzi pomiędzy przyczynami a ich źródłem i partycypacją w tym źródle, a z drugiej strony nad ewentualnym porządkiem wśród przyczyn. Eriugena wskazuje, że ów porządek jest tylko układem wywnioskowanym na potrzeby ludzkiego poznania i nie dotyczy przyczyn w sensie właściwym. Przyczyny w swej istocie są czymś jednym i prostym, a tam gdzie zachodzi jedność i prostota dodatkowe porządki są zbędne. Eriugena przyjmuje, że przyczyny są jednocześnie wieczne i stworzone, a relacja, która zachodzi pomiędzy Bogiem

\footnotetext{
${ }^{19}$ Platon, Hippiasz większy 291 d, Dialogi, t. I, dz. cyt., s. 175.

${ }^{20}$ Platon, Fedon 78d, Dialogi, t. I, dz. cyt., s. 660.

${ }^{21}$ Zob. Pseudo-Dionizy Areopagita, Hierarchia niebiańska IV, 1, [w:] Pisma teologiczne II, przeł. M. Dzielska, Znak, Kraków 1999, s. 62.
} 
i przyczynami ma typowo poznawczy charakter. Stwarzając rzeczy, Bóg je poznaje. Wszystko zostało poznane przez Boga zanim zostało stworzone. Przyczyny zostały stworzone - ustanowione w Logosie, o którym Eriugena mówi: „Przeto Syn Boży jest duchem, czyli pojmowaniem wszystkich rzeczy. On sam bowiem, zgodnie z tym, co mówi święty Augustyn, jest pojmowaniem wszystkich rzeczy, a nawet [jest On] wszystkim"22. Bóg Syn - Logos posiada realne istnienie, więc przyczyny również realnie istnieją w poznawczym sensie, ponieważ wiadomo, że zostały ustanowione w Logosie. Bóg obejmuje wszystkie rzeczy swoją gnostyczną mocą. Eriugena pisze:

Jeśli bowiem pojmowanie wszystkich rzeczy jest wszystkimi rzeczami, a Ona sama pojmuje wszystkie rzeczy, to wobec tego Ona sama jest wszystkimi rzeczami, ponieważ jedynie Ona sama jest gnostyczną Mocą, która poznała wszystkie rzeczy zanim zaistniały. A wszystko poznała w sobie samej, a nie poza sobą, ponieważ poza nią nic nie istnieje. Istotnie, obejmuje Ona wszystkie rzeczy, a wszystko, co jest w Niej, o ile prawdziwie istnieje, jest Nią samą, która jako jedyna prawdziwie istnieje. Pozostałe zaś rzeczy, o których orzeka się byt, są jej teofaniami, które również w Niej prawdziwie istnieją. I w taki sposób Bóg jest wszystkim, co prawdziwie istnieje, ponieważ On sam czyni wszystko i staje się we wszystkim, jak mówi święty Dionizy Areopagita ${ }^{23}$.

Wszystko, co zostało stworzone, wcześniej zaistniało w stwórczej świadomości Boga, nazwanej gnostyczną mocą. Ta moc jest siłą sprawczą, która realizuje własne skutki. Dzieje się tak, ponieważ dla Boga chcenie, widzenie, działania i poznawanie oznaczają to samo. Przyczyny ustanowione w Logosie świadczą o porządku Bożej mądrości. Ta ważna funkcja zaświadczania powoduje, że stworzenie jest Bożą teofanią rozumianą jako dostępny w określonej mierze dla ludzkiego poznania aspekt niedostępnego dla ludzkiego poznania Boga. W sensie poznawczym przyczyny prymordialne realnie istnieją, ponieważ, podobnie jak idee w systemie Platona, są bytami wiecznymi (choć

${ }^{22}$ Eriugena, Komentarz do Ewangelii Jana $z$ Homilią do Prologu Ewangelii Jana, przeł. A. Kijewska, ANTYK, Kęty 2000, s. 78-79.

${ }^{23}$ Eriugena, Periphyseon, Ksiega III, dz. cyt., s. 95 oraz s. 94 za Eriugena, Periphyseon, liber tertius: Si enim intellectus omnium est omnia et ipsa sola intelligit omnia, ipsa igitur sola est omnia, quoniam sola gnostica virtus est ipsa quae, priusquam essent omnia, cognovit omnia. Et extra se non cognovit omnia, quia extra eam nihil est, sed intra se. Ambit enim omnia et nihil intra se est, in quantum vere est, nisi ipsa, quia sola vere est. Caetera enim, quae dicuntur esse, ipsius theophaniae sunt, quae etiam in ipsa vere subsistunt. Deus est itaque omne quod vere est, quoniam ipse facit omnia, et fit in omnibus, ut ait sanctus Dionysius Ariopagita. 
stworzonymi) i charakteryzują się jednością oraz prostotą: „A owe przyczyny ujęte w sobie samych są czymś jednym, prostym i nie są określone czy oddzielone od siebie wzajemnie jakimś poznanym przez kogoś porządkiem, gdyż podlegają mu jedynie w swoich skutkach" ${ }^{24}$. Nie oznacza to jednak, że mają realny, niezależny od wszystkiego ontologiczny byt, ponieważ prawdziwie istnieje tylko Bóg. Przyczyny istnieją w Bogu - Logosie, ale nie są Bogiem. Bóg jest niestworzony i ma realny byt, przyczyny są radykalnie inną rzeczywistością - są stworzeniem, więc nie mają realnego bytu.

\section{Autonomia idei i przyczyn prymordialnych}

Platońskie idee są autonomiczne w tym sensie, że nie zachodzi jakakolwiek relacja zależności idei od sfery rzeczy zmysłowych. Idee stanowią racje istnienia dla rzeczy, ale ta relacja nigdy nie jest odwracalna. W Eutyfronie Platon pisze: „Otóż przypominasz sobie, że nie o to cię prosiłem, abyś mnie pouczył o jednym czy dwóch spośród wielu przypadków zbożności, ale o jej formie samej, przez którą wszystko, co zbożne, jest zbożne [...]"25. W Fedonie Platon zwraca uwagę, że to, co charakteryzuje się prawdziwym istnieniem, musi być wieczne i niezmienne ${ }^{26}$. Idee, które realnie istnieją, są bytami autonomicznymi, ponieważ mają niezależne od rzeczy, niezmienne istnienie. Autonomia idei wynika również z faktu, że można je, w przeciwieństwie do rzeczy zmysłowych, uchwycić tylko wysiłkiem ludzkiego rozumu ${ }^{27}$. Odnosząc problem autonomii idei do ludzkiej duszy i ciała, Platon pisze: „[...] do tego, co boskie i nieśmiertelne, i dla myśli tylko dostępne, i jedną tylko postać mające, i nierozkładalne, i zawsze samo w sobie jednakie, najpodobniejsza jest dusza; a do tego, co ludzkie i śmiertelne, i bezmyślne, i wielopostaciowe, i rozkładalne, i zawsze samo w sobie wielorakie, najpodobniejsze znowu jest ciało" ${ }^{28}$. Każda idea jest, według Platona, wieczną i niezmienną, więc w pełni absolutną normą. Każda idea jest tożsama $\mathrm{z}$ sobą i dla realnego istnienia oraz

\footnotetext{
${ }^{24}$ Tamże, s. 65-67 oraz s. 64-66 za Eriugena, Periphyseon, liber tertius: Ipsae siquidem prime causae in se ipsis unum sunt et simplices nullique cognito ordine diffinitae aut a se invicem segregatae; hoc enim in effectibus suis patiuntur.

${ }^{25}$ Platon, Eutyfron 6d, Dialogi, t. I, dz. cyt., s. 522.

${ }^{26}$ Zob. Platon, Fedon 78cd, Dialogi, t. I, dz. cyt., s. 660.

${ }^{27}$ Zob. tamże, 79a, s. 660.

${ }^{28}$ Tamże, 80b, s. 663.
} 
bycia tym, czym jest w żadnej mierze nie potrzebuje rzeczy, dla których sama stanowi rację ich istnienia i ich istotę, a tym bardziej nie potrzebuje żadnych innych rzeczy. W tym sensie platońskie idee są w pełni autonomiczne.

Przyczyny prymordialne zostały ustanowione w Bogu Logosie, więc zaistniały jako stworzone, choć jednocześnie wieczne oraz proste. Fakt ten powoduje, że przyczyny nie są autonomiczne w znaczeniu absolutnym, ponieważ nie są Bogiem, a absolutna autonomia przysługuje tylko Bogu. Przyczyny są stworzone przez Boga i podtrzymywane $\mathrm{w}$ istnieniu, więc $\mathrm{w}$ neoplatońskiej strukturze rzeczywistości Eriugeny, stanowią jako stworzenie radykalnie odmienną sferę niż niestworzony Stwórca, więc nie mogą mieć wobec Boga charakteru autonomicznego, ponieważ nic nie może posiadać takiego charakteru wobec samego Stwórcy. Inaczej jednak wygląda relacja przyczyn do ich skutków. Przyczyny zaistniały w Logosie z potencjałem swych skutków, lecz rzeczy, które stanowią skutki przyczyn nie zaistniały jeszcze wówczas $\mathrm{w}$ tej formie, w której dostępne są zmysłom. Skoro więc istniały przyczyny bez swych, zwłaszcza zmysłowych skutków, to można przyjąć, że w systemie Eriugeny przyczyny nie potrzebują do swego istnienia żadnych nośników, zwłaszcza materialnych. Wynika z tego, że przyczyny są bytami autonomicznymi wobec rzeczywistości swych skutków.

\section{Zakończenie}

W systemie filozoficznym Platona najwyższe zasady Jedno i Diada uzasadniają, lecz nie stwarzają idei, które są bytami wiecznymi, czyli niestworzonymi. Idee nie mają źródła, ponieważ istnieją zawsze i pozostają niezmienne. Nigdy nie istniała jakakolwiek rzeczywistość bez idei, które są bytami realnymi, ponieważ istnieją jako całkowicie niezależne od bycia czymkolwiek innym niż tym, czym są. Idea nie może być niczym innym niż tym czym jest. Niezłożoność, prostota, jednorodność i niemożliwość realnego istnienia przeciwieństwa idei potwierdzają realność ich istnienia. Idee są autonomiczne, ponieważ nie zachodzi jakakolwiek relacja ich zależności od rzeczy zmysłowych. Stanowią racje istnienia rzeczy, ale ta relacja nigdy nie jest odwracalna. $\mathrm{O}$ autonomii idei świadczy fakt, że w przeciwieństwie do rzeczy, idee można uchwycić tylko wysiłkiem ludzkiego rozumu. Każda idea jest autonomiczna, ponieważ nie potrzebuje niczego do bycia tym, czym jest. 
W systemie filozoficznym Eriugeny źródłem przyczyn prymordialnych jest Boża mądrość - Słowo-Syn-Logos. Bóg Ojciec zrodził Syna i ustanowił w Nim wieczne przyczyny wszystkiego. Logos jest zrodzony, natomiast przyczyny są ustanowione - stworzone. Nigdy nie było takiego stanu, że przyczyn w Logosie nie było, więc wieczność przyczyn wynika $\mathrm{z}$ wieczności Logosu. Przyczyny istnieją realnie w sensie poznawczym, lecz nie posiadają realnego istnienia w absolutnym sensie ontologicznym. Są bytami prostymi, świadczącymi o Bożej mądrości i podobnie jak platońskie idee, są bytami wiecznymi oraz charakteryzują się jednością, lecz nie oznacza to absolutnego realnego istnienia w sensie ontologicznym. Przyczyny istnieją w Bogu Logosie, ale nie są Bogiem, a realne istnienie przysługuje tylko Bogu. Przyczyny rozpatrywane od strony ich skutków są autonomiczne, ponieważ nie zachodzi jakakolwiek relacja ich zależności od skutków. Podobnie jak idee, przyczyny stanowią racje istnienia swych skutków i ta relacja nigdy nie jest odwracalna. O autonomii przyczyn świadczy również fakt, że można je uchwycić tylko wysiłkiem ludzkiego intelektu. Przyczyny nie mają jednak takiej autonomii jak idee, ponieważ w sensie ontologicznym są całkowicie zależne od Boga, który je powołał do istnienia i umożliwia to istnienie. Bytem autonomicznym jest tylko Bóg, a przyczyny są radykalnie różne od niestworzonego Boga, ponieważ zostały przez Boga ustanowione, a więc nie są bytami autonomicznymi w sensie absolutnym.

Idee będące fundamentem systemu Platona oraz przyczyny prymordialne stanowiące jeden $\mathrm{z}$ czterech elementów podziału natury w systemie Eriugeny, rozpatrywane w kontekście ludzkiego poznania, mają ważne wspólne cechy, ponieważ są bytami realnymi i autonomicznymi. Istotne różnice pojawiają się, gdy idee i przyczyny są rozpatrywane w kategoriach ontologicznych. Różnice te wynikają z faktu, że Platon nie mógł znać chrześcijaństwa, choć jego system filozoficzny bardzo przyczynił się do rozwoju tej religii. Chrześcijański neoplatonik Eriugena uważał Platona za najwybitniejszego z filozofów ${ }^{29}$. Platońskie idee nie mogły jednak w chrześcijańskim systemie Eriugeny pozostać niestworzonymi bytami istniejącymi realnie same przez się $\mathrm{z}$ absolutną autonomią. Eriugena przyjął, że prawdziwie istnieje tylko transcendentny Bóg, który sam jest niestworzony i w swym zrodzonym Synu ustanowił idee przyczyny prymordialne - pierwotne przyczyny wzorcze całego stworzenia. Bóg jako niestworzona natura stwarzająca jest źródłem idei - przyczyn, które stanowią w systemie Eriugeny stworzoną naturę stwarzającą.

${ }^{29}$ Zob. Eriugena, Periphyseon, Ksiega III, dz. cyt., s. 385. 


\section{Bibliografia}

Eriugena Jan Szkot, Komentarz do Ewangelii Jana z Homilia do Prologu Ewangelii Jana, przeł. A. Kijewska, ANTYK, Kęty 2000.

Eriugena Jan Szkot, Periphyseon, Księga I, przeł., wstępem i komentarzami opatrzyła A. Kijewska, Wydawnictwo Marek Derewiecki, Kęty 2009.

Eriugena Jan Szkot, Periphyseon, Księga II, przeł., wstępem i komentarzami opatrzyła A. Kijewska, Wydawnictwo Marek Derewiecki, Kęty 2010.

Eriugena Jan Szkot, Periphyseon Księga III, przeł., wstępem i komentarzami opatrzyła A. Kijewska, Wydawnictwo Marek Derewiecki, Kęty 2010.

Kijewska A., Ksiega Pisma i Ksiega Natury. Heksaemeron Eriugeny i Teodoryka $z$ Chartres, Wydawnictwo KUL, Lublin 1999.

Otten W., Nature and Scripture: Demise of Medieval Analogy, „Harvard Theological Review" 88/2, 1995.

Platon, Dialogi, t. I, przeł. oraz wstępami i objaśnieniami opatrzył W. Witwicki, ANTYK, Kęty 2005.

Platon, Państwo, przeł., wstępem i komentarzami opatrzył W. Witwicki, ANTYK, Kęty 2003.

O'Meara D. J., Eriugena's Use of Augustine's „De Genesi ad litteram” in the „Periphyseon", w: Studies in Augustine and Eriugena, ed. T. Halton, The Catholic University of America Press, Washington 1992.

Pseudo-Dionizy Areopagita, Hierarchia niebiańska IV, 1, w: Pisma teologiczne II, przeł. M. Dzielska, Znak, Kraków 1999.

Reale G., Historia filozofii starożytnej, t. II: Platon i Arystoteles, przeł. E. I. Zieliński, RW KUL, Lublin 1996.

Syrianus, Syriani In Metaphysica commentaria, ed. G. Kroll, Commentaria in Aristotelem Graeca, Berolini, Berlin 1902.

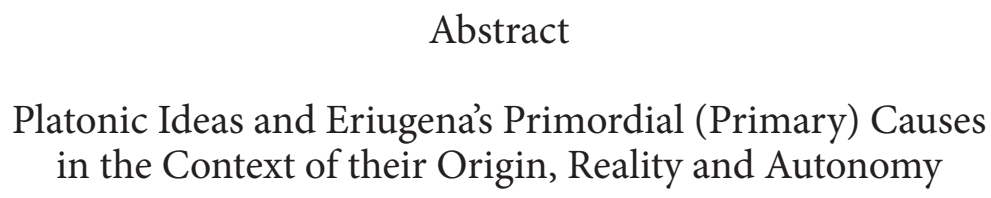

In Plato's philosophical system, ideas are eternal and immutable entities that are autonomous and real. Phenomena are what they are because they participate in ideas. In the philosophical system of Eriugena, the primordial (primary) causes are eternal but God-created beings. Primordial causes really exist thanks to God and are autonomous in relation to their effects. Absolutely real and autonomous is God alone. The article is an attempt to show the ideas and causes in terms of their origin, 
reality, and autonomy. It is worth, according to the author, an attempt to compare and compile the results, because Plato and Christian Neoplatonist Eriugena are significant figures for European culture and our civilization.

Key words: Plato, Eriugena, ideas, causes, source of origin, reality of existence, autonomy 